\title{
Application Research about the University-enterprise Cooperation of Civil Engineering Specialty in Higher Vocational Colleges under Information Environment
}

\author{
Sun Shu, Liu Ru-bing and Gu Sheng \\ Taizhou Polytechnic College \\ Taizhou, Jiangsu 225300
}

\begin{abstract}
The strong comprehensiveness and practicalness that the civil engineering specialty in higher vocation colleges bear make a request for not only the students' good professional knowledge, but also certain operation capacity. However, problems such as the imperfect cooperation mechanism the imperfect teaching staffs, and insufficient internships in the teaching process of traditional university-enterprise cooperation make it difficult for students to internalize the knowledge. However, through the integration of information technology, course knowledge and professional posts in virtual environment, students can conduct real work through the teaching platform, and deepen the understanding of knowledge and posts through comprehensive three-dimensional communication, timely solve the problems encountered in their study thus to achieve the good teaching effects.
\end{abstract}

Keywords-Information technology; University-enterprise cooperation; Virtual simulation; Autonomic learning

\section{INTRODUCTION}

The civil engineering specialty in higher vocational colleges has characteristics of strong comprehensiveness, strong practicalness and close connection with engineering practice, so the concept of university-enterprise cooperation had entered into the practical teaching of the specialty a long time ago. University-enterprise cooperation refers to establishing the alliance and cooperative relationship of mutual benefit, mutual supplementation and mutual promotion between universities and enterprises considering talent cultivation, scientific research, technical development, resource sharing, personnel communication, and other aspects. It is not only the reform and development requirements of higher vocational colleges, but also the necessary requirement for enterprises to gain excellent talents and improve enterprise competitiveness [1].

Currently, overseas university-enterprise cooperation has many teaching modes, for instance, German "double-track approach" mainly refers to the parallel implementation of students considering the study of actual operation skills in enterprises and the study of theoretical knowledge in vocational schools; Canadian CBE (Competency Based Education) emphasizes that the enterprise demand is not only

Fund Project: Key Topics for the Higher Education Teaching Reform Research of Jiangsu Province in 2015 (2015JSJG98), Taizhou Polytechnic College Vocational Education Research 2016 Topic (ZY201606, ZY201604) the starting point for schools but also the incidence point; the teaching factory mode of Singapore is to provide a true factory production environment to students, and let students master knowledge and skills through production practice; British GHD and Open University adopt university-enterprise resource sharing, and implement on-campus and off-campus network mutual-connection, conduct open type online management and use, and realize the diversified teaching and learning demand of universities and enterprises[2]. However, domestic university-enterprise cooperation is started late, with fast speed and various modes (currently, the teaching mode for university-enterprise cooperation in higher vocational colleges of our country mainly includes project-oriented mode, courseoriented mode, university-enterprise integration mode and "order" mode)[3], and the occurrence and implementation of these modes have largely improved the previous shortcomings in traditional teaching, such as unclear teaching objective and backward knowledge, but there are still many problems.

\section{PROBLEMS IN UNIVERSITY-ENTERPRISE COOPERATION}

Firstly, the cooperation mechanism system is imperfect. Our country still has no laws or regulations to follow considering university-enterprise cooperation, and this has made the current period of university-enterprise cooperation be kept at the initial period, and most of the time, it will fully rely on personal relationship. There are differences in the appeal of universities and enterprises; enterprises want the universities to directly cultivate excellent students with complete knowledge to serve for them, and don't want to spend time and cost in providing service to schools, and during the cooperation, they can lack of imitative and enthusiasm. However, schools want enterprises to actively participate in talent cultivation process, but they cannot put forward conditions that can impress enterprises. This has made the two parties fail to reach an agreement during cooperation, and cannot truly exert the advantages of university-enterprise cooperation. Therefore, the state needs to fully play the initiative (tax reduction and exemption, policy support, etc.) of enterprises, and form university-enterprise in-depth cooperation, collaborative talent cultivation, mutual benefit, and win-win long-term mechanism, provided that enterprise interests can be protected through laws and regulations. 
Secondly, the teacher team is to be completed. Complete teacher team is the essence for modern higher vocational education, and also the key for carrying out course reform. But currently, the teacher team in higher vocational colleges has many problems. The professional teachers at school lack of enterprise working experience, with insufficient engineering experience, low practical operation level, and insufficient power for course reform and construction, and this has made the teaching contents of many courses be restricted by traditional subject system, the teaching contents cannot be consistent with the post demand, and the knowledge capacity is seriously lagged behind the requirements for modern construction. The teaching mode cannot adapt to the students' capacity, or stimulate students' learning interest. As for parttime teachers from enterprises, they have heavy enterprise task, and cannot spend lots of time comprehensively guiding students' course; besides, they have low education background or teaching experience, and cannot teach their knowledge to students within a short time.

Finally, the practical training conditions are insufficient. In the recent years, the state has largely increased the input in education career, and the practical training conditions in higher vocational colleges are also obviously improved. However, many problems are found in the practical training process, such as uneven quality of practical training equipment, inconsistence with the actual production, extensive management, low using rate, and the high fault rate incurred by the irregular utilization of students. Besides, in consideration of the safety of students in practical training process, most of higher vocational colleges don't want to input lots of expenditures into the construction of practical training base, and can only meet the basic teaching related experiments.

In light of the aforementioned disadvantages, enterprises and universities should constantly summarize experience and disadvantages in the cooperation process, and jointly discuss about the research strategy. Along with the development of information technology, the trend of education resource digitalization has gradually become the trend for the development of higher vocational colleges. Through practical investigation and demonstration, experts of enterprises and universities should pay high attention to information technology resources, and put forward the gradual construction of a kind of teacher and talent cultivation strategy and teaching mode under information technology environment, so as to realize the elimination of original disadvantages, and obtain a better education teaching effect and talent cultivation objective, ensure that students of higher vocational colleges can better adapt to the demand of future enterprise work, and realize the cooperation optimization of two parties. In view of this, this article puts forward the application of information technology means to transplant the construction site to the teaching mode integrating colleges, knowledge dynamics, course authentication and teacher cultivation, and attempts to reach to the enterprise talent continuous education and college talent cultivation demand through practice.

\section{INFORMATION TECHNOLOGY IS A GOOD RECIPE FOR SOLVING THE CURRENT DILEMMA}

(1) Information technology can express the previously difficult and boring theoretical knowledge through a more visual and specific way. In the previous traditional infuseteaching mode, students will firstly understand, process, and then absorb the information taught by teachers, and such process requests students to have enough focus and imagination, and these are requirements hard to be met for students of higher vocational colleges during the current period. Information teaching can let students directly observe or operate and experience through information technology and let them master knowledge and skills, and simplify the information transmission process. Famous Educator Montessori said that "I will forget it when I see it; I will remember it when I hear it; and I will understand it when I do it". Through personally experiencing the work process, students can define learning objective, practiced labor skills, understood the relationship of courses and posts, and shortened the route of knowledge transmission. Information technology will certainly improve the teaching effect to a large extent.

(2) Virtual simulation practical training room can solve practical training difficulty of students. Except for requesting students to conduct necessary theoretical basis, higher vocational education also requests students to possess stronger practical operation capacity. Traditional practical training link requires to be completed by students at the practical training site on campus or in the enterprise, but such learning process should consider students' safety, instrument damage, time schedule and other problems, and generally, it will get half the result with twice the effort. However, through the school, enterprise and software vendor jointly fabricate virtual simulation practical training room, students can learn practical training projects with expensive price, easily damaged feature and high risk through VR\AR and other technologies in virtual simulation environment, and through virtual simulation practical training, they can also complete the study of instrument preparation, instrument operation, data processing, fault elimination and other aspects, reinforce the understanding and mastering of practical training process, reduce operation error, largely decrease instrument damage rate, and largely improve teaching quality.

(3) Solve the learning problems of students through transtime-and-space communication. The previous learning motivation of students is insufficient, and the main reason is that the learning objective is unclear, and students cannot understand the benefits brought to the future work after learning the course. In the previous traditional universityenterprise cooperation, this is generally solved through the mode of inviting enterprise experts to give lecture and salon to students at school, but such concentrated teaching mode is far away from students, with short time, and students cannot fast digest the information transmitted by experts within a short time, and the learning effect is relatively bad. Through remote network teaching platform and social software, students, tutors on campus, enterprise tutors, and the previous excellent graduates can be organized, and conduct real-time communication before class, in the class and after the class, and when students are encountering with problems or 
enterprise tutors are encountering with teaching point at site, they can communicate immediately, and with photos, videos and site explanation being integrated, it can facilitate the learning process of students and make it more direct and vivid. Through three-dimensional and multidimensional communication, problems such as unclear learning objective of students and the problem of no one answering questions when there is confusion; meanwhile, this can also avoid students from self-exile, and even addicted to network games and thoroughly losing the direction due to the aforementioned reasons.

As for the school, information technology has solved the problems of difficult theoretical knowledge internalization of students and the difficult management of practical training link. It can transfer the dangerous and complicated work site within the internship and practice link of students to clean and neat computer room, and this can solve the practical training safety of students and the problem of meeting practical training conditions. Information technology can not only improve teaching quality, but also decrease teaching cost, and meanwhile, solve the problem of non-unified practical training evaluation standard of enterprises, and the problem of ensuring the practical training quality of students, and make universityenterprise cooperation be successfully operated.

As for enterprises, they don't need to worry about the safety and management of students, or the arrangement of work shift for the short-term practical training of students. Meanwhile, the understanding of enterprises about their own future employees will no longer rely on a piece of transcript, or several certificates of merit, but the comprehensive evaluation of students' achievements through virtual simulation practical training achievement, theoretical achievement, practical operation achievement, etc. Meanwhile, while conducting video communication, they can also have a more clear understanding about the comprehensive quality of students, and make preparations for them to choose more suitable talents.

\section{OVERAll Design of ViRTUal Simulation TEACHING SYSTEM}

Through information technology, BIM technology and various kinds of application technology software as well as task-driven mode and edutainment (games) and other modes, the system can realistically restore the construction site through three-dimensional display form, and let students master correct construction technology, and meanwhile, understand the entire management process of projects, and then cultivate management talents for enterprises. The employment direction for students majoring in civil engineering in higher vocational colleges is mainly focused on the building construction enterprise units, supervision units and small-scaled cost units, so virtual practical training tasks are also mainly positioned at the construction period for the full life circle of construction engineering. There are mainly 8 types of working post, including the constructor, cost engineer, and data processor, but after aggregation merger, finally, three system simulation roles will be formed, i.e., the constructor, the cost engineer and data processor.
Students can work with the working role of constructor, cost engineer, data processor, etc., to understand the work task requested to be completed for each post in the building construction process, and through task-driven and projectleading mode, they can master the knowledge and working skills requested for each post. Students can understand how to construct buildings and the task requested to be completed within the system, and such virtual environment has shortened the transition time for students from schools to enterprises, and decreased the adaptation difficulty. Meanwhile, the progress control of the system is more flexible than actual projects, with more observation angles, and students can complete the entire study within a short time.

The engineering selected by the system is commercial and residential complex building, and the foundation is pile foundation, $-1 \mathrm{~F}$ and $1 \mathrm{~F}-5 \mathrm{~F}$ are framed shear wall structure, and floors above $6 \mathrm{~F}$ are shear wall structure, the construction height is above $90 \mathrm{~m}$, and the total construction area is above $60,000 \mathrm{~m} 2$, and it has included the existing main-steam construction technologies. It takes the construction management procedures and construction technology of actual construction site as the main line, divides tasks with construction subprojects, and divides the entire engineering into 5 subprojects, and totally 49 modules, and the layout of software in the entire construction site shall be erected as per the requirements of safe, civilized and standardized construction site, and the construction process shall follow the quality requirements of Luban Prize (Luban Prize is the highest honor award of engineering quality for domestic construction industry), implement high standard and strict requirements, so as to lay a solid foundation for the future work of students.

In the system, except for the materials, machinery, tools and equipment used in the construction process, which can make students initially understand about the structure, working principle and operation methods of these equipment, etc., it also includes all the construction data requested for the construction process, such as the construction drawing, construction scheme, investigation report, technical disclosure, safety disclosure, construction records, quality inspection report, concealment engineering verification record, quality acceptance records, the relevant standard atlas, which can let students simultaneously learn the content format of construction data, etc., so as to understand the importance of data in construction. Each practical training module is equipped with Practical Training Assignment Book, to guide students to complete each practical training task, and finally form practical training report, and let students learn with objectives, have a definite object in view and improve learning efficiency. The main function of the software includes autonomous roam, technology display, simulation operation, online evaluation, component and fitting cognition, database safety management, detail structure display, node diagram, and code requirement explanations and other functions. 


\section{SUMMARY}

Currently, due to the decrease of student source for college entrance examination and the extrusion of undergraduate universities, the quality of student source in higher vocational colleges is decreased to some extent when being compared with the past. Students have certain barrier in the digestive absorption of knowledge, and have weak operation capacity. Meanwhile, construction industry belongs to high-risk industry, and due to the restriction of time, safety, resources, etc., it is impossible to fully realize the idea of letting students observe the construction site, and practice, and in most cases, schools don't want to conduct configuration due to problems such as the expensive and easily damaged practical training equipment, and low using rate. This has made it impossible to correspond the knowledge learned by students to the working post, and then caused the loss of learning interest, and intensify the learning-weariness mind of students. With the help of software vendors, university-enterprise cooperation is engaged in jointly developing virtual simulation practical training room and exchange platform, and through the virtual simulation teaching platform, teachers and students can understand knowledge and post capacity requirements through games, actual situation observation and actual projects, etc., reinforce the space-time understanding, post understanding, and process understanding of building construction, etc., and the problems faced by students in study can be effectively and fast answered; besides, this can also improve the learning interest of students, and reach a good teaching effect.

\section{REFERENCES}

[1] Ma Hongjie. Research about the Construction of Campus Culture in Higher Vocational Colleges [D]. Xi'an University of Architecture and Technology, 2009.

[2] Wang Jian. Practice Research about the University-enterprise Cooperation Teaching Mode in Higher Vocational Colleges under Information Technology Environment [D]. Nanjing Normal University, 2006.

[3] He Xiaochun and Zhou Yanchun. Practice and Discussion of "Fourparty Linkage" University-enterprise Cooperation Mode in Higher Vocational Colleges [J]. Journal of Nantong Vocational University, 2008, 01: 33-36.

[4] Liu Shaokui. Discussion about the Labor Law Protection of Intern Students in Colleges [J]. Legal System and Society, 2015, 10: 293-296.

[5] Xu Yiliang. Problems in Off-campus Internship and the Solutions [J]. Vocational Education Research, 2004, 05: 76-77.

[6] Shi Weiping. Carrying out Live-action Teaching through Multiple Channels and Cultivating Talents for Modern Service Industry [J]. Chinese Vocational and Technical Education, 2013, 05: 53-56.

[7] Zhang Xuegang and Zhou Xiaofeng. Research about the Virtual Simulation Practical Training System for Construction Engineering Speciality in Higher Vocational Colleges [J]. Chinese Vocational and Technical Education, 2014, 23: 25-27.

[8] Wang Xingji. Thoughts about the Construction of Engineering Management Simulation Practical Training Environment for Highe Vocational Colleges [J]. Vocational \& Technical Education Forum, 2012, 26: 54-56.

[9] Sun Yuying, Gai Yijing, Wang Wei, Wu $\mathrm{Xu}$, and Hong Yang. Development of Virtual Simulation Teaching and Practical Training Platform for Air Conditioning Ventilation System Pipe Network Performance [J]. Journal of Engineering Graphics, 2016, 04: 550-555. 